\title{
Kupffer Cell Transplantation in Mice for Elucidating Monocyte/Macrophage Biology and for Potential in Cell or Gene Therapy
}

Simone Merlin, ${ }^{*}$ Kuldeep K. Bhargava, ${ }^{\dagger}$ Gabriella Ranaldo, ${ }^{*}$ Diego Zanolini, ${ }^{*}$ Christopher J. Palestro, ${ }^{\dagger}$ Laura Santambrogio, ${ }^{\dagger}$ Maria Prat, ${ }^{*}$ Antonia Follenzi, ${ }^{* \ddagger}$ and Sanjeev Gupta ${ }^{\ddagger \S}$

From the Department of Health Sciences, * Università del Piemonte Orientale "A. Avogadro", Novara, Italy; the Division of Nuclear Medicine and Molecular Imaging, ${ }^{\dagger}$ North Shore - Long Island Jewish Health System, New Hyde Park, New York; and the Department of Pathology $y^{\ddagger}$ and the Department of Medicine, ${ }^{\S}$ Marion Bessin Liver Research Center, Cancer Research Center, Diabetes Center, Ruth L. and David S. Gottesman Institute for Stem Cell and Regenerative Medicine Research, and Institute for Clinical and Translational Research, Albert Einstein College of Medicine, Bronx, New York

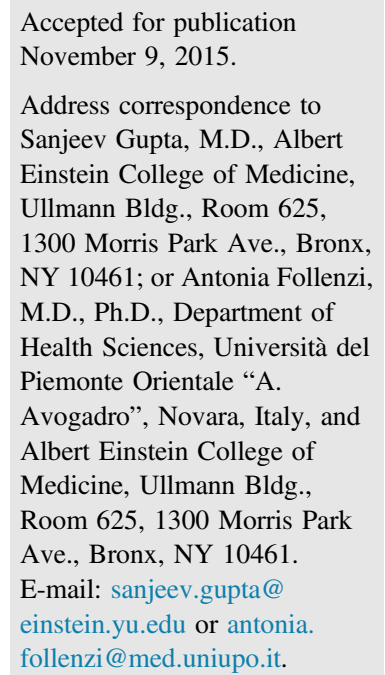

\begin{abstract}
Kupffer cells (KC) play major roles in immunity and tissue injury or repair. Because recapitulation of KC biology and function within liver will allow superior insights into their functional repertoire, we studied the efficacy of the cell transplantation approach for this purpose. Mouse KC were isolated from donor livers, characterized, and transplanted into syngeneic recipients. To promote cell engraftment through impairments in native $\mathrm{KC}$, recipients were preconditioned with gadolinium chloride. The targeting, fate, and functionality of transplanted cells were evaluated. The findings indicated that transplanted KC engrafted and survived in recipient livers throughout the study period of 3 months. Transplanted KC expressed macrophage functions, including phagocytosis and cytokine expression, with or without genetic modifications using lentiviral vectors. This permitted studies of whether transplanted $\mathrm{KC}$ could affect outcomes in the context of acetaminophen hepatotoxicity or hepatic ischemia-reperfusion injury. Transplanted KC exerted beneficial effects in these injury settings. The benefits resulted from cytoprotective factors including vascular endothelial growth factor. In conclusion, transplanted adult $\mathrm{KC}$ were successfully targeted and engrafted in the liver with retention of innate immune and tissue repair functions over the long term. This will provide excellent opportunities to address critical aspects in the biogenesis, fate, and function of $\mathrm{KC}$ within their native liver microenvironment and to develop the cell and gene therapy potential of KC transplantation. (Am J Pathol 2016, 186: 539-551; http:// dx.doi.org/10.1016/j.ajpath.2015.11.002)
\end{abstract}

The ability to reconstitute Kupffer cells (KC) in the liver by the cell transplantation approach will be significant for studies of the biology and pleiotropic functions of $\mathrm{KC}$. Replacement of hepatocytes and liver sinusoidal endothelial cells has been helpful for biological studies and cell therapy, including for coagulation defects, as in hemophilia A. ${ }^{1-3}$ Because $\mathrm{KC}$ represent $5 \%$ to $15 \%$ of liver cells and constitute $80 \%$ of resident macrophages in the body, ${ }^{4}$ having a better understanding of their roles in tissue homeostasis, injury, or repair is clinically very relevant, but the origin of $\mathrm{KC}$ has been complex, since $\mathrm{KC}$ may arise within the liver as well as outside of the liver [ie, from bone marrow-derived monocyte/macrophage (BMDM) lineages]..$^{5-7}$ If candidate macrophage populations were transplanted successfully in the liver with engraftment and survival over the long term, major issues could be addressed regarding their roles in microbial clearance, antigen presentation, tissue

\footnotetext{
Supported in part by NIH grants R01 DK071111, R01 DK088561, P30 DK41296, and P30 CA13330 (S.G.) and Ricerca Sanitaria Finalizzata della Regione Piemonte, Progetti di Rilevante Interesse Nazionale (Project of Significant National Interest; PRIN) 2008 from Italian Ministry of Education, GGP09280 by Telethon Foundation Italy, and European Research Council (ERC) startup grant 261178 (A.F.).

The views expressed in this article are the authors' own and not an official position of the institutions or funders.

Disclosures: None declared.
} 
inflammation or repair, ${ }^{6-9}$ ischemia-reperfusion (IR) preconditioning, for example, in which complex cytokine, chemokine, or receptor networks are involved but are difficult to reproduce in conditions other than in vivo. ${ }^{10-13}$

Success in transplanting $\mathrm{KC}$ also will offer tools to determine whether cell types of interest may be cotransplanted for protecting transplanted cells and thereby improving liver repopulation. For instance, transplantation of adenovirally transduced nonparenchymal liver cells (NPC) expressing superoxide dismutase decreased acute IR injury in rats. ${ }^{14}$

Recently, $\mathrm{KC}$ were discovered to express coagulation factor VIII, and transplantation of healthy $\mathrm{KC}$ improved blood clotting in hemophilia A mice. ${ }^{15}$ On the other hand, putative connections in $\mathrm{KC}$ and BMDM gained interest, such as exemplified by transplantation of peripheral blood monocytes/ macrophages or BMDM in liver disease,,${ }^{16,17}$ or of geneticallymodified BMDM expressing heme oxygenase -1 to improve survival of liver grafts. ${ }^{18}$ However, the extent by which transplanted monocytes/macrophages may engraft, survive, and function is not well understood. ${ }^{16}$ Although bone marrow $(\mathrm{BM})$-derived mononuclear cells may generate $\mathrm{KC}$ or myofibroblasts in animals, ${ }^{19}$ whether transplanted BMDM may engraft and survive over the long term, is also unclear. ${ }^{16,20}$

This study determined whether KC could be transplanted successfully in the liver. Although homogeneous cell populations should be helpful for this purpose, phenotypic markers often overlap in given cell populations..$^{5-7,9,21}$ In case of macrophages, CD11b, F4/80, CD68, and other markers have been useful, ${ }^{22-24}$ especially when contaminating cell types sharing these markers are eliminated. Therefore, before digesting liver to release $\mathrm{KC}$, we cleared cells from liver sinusoids to avoid contamination with neutrophils, monocytes, or other blood cells. Also, we used mouse BM-derived monocyte/macrophage progenitors, BMDM, peritoneal macrophages (PM), and tail-tip fibroblasts (TTFs) for comparisons. To improve cell engraftment, we depleted $\mathrm{KC}$ with gadolinium chloride before cell transplantation, and we also transplanted $\mathrm{KC}$ after geneticmodification with lentiviral vectors (LV). For determining phenotype-specific effects of transplanted $\mathrm{KC}$ within the context of cytokine expression in liver microenvironment, we used acetaminophen (APAP)- or IR-induced liver injury models. ${ }^{25-27}$

\section{Materials and Methods}

\section{Animals}

Animal Care and Use Committees of Albert Einstein College of Medicine and University of Piemonte Orientale approved studies. Mice were 7 to 10 weeks old. Donors were wild-type C57BL/6J mice, C57BL/6-Tg(CAG-EGFP) $131 \mathrm{Osb} /$ LeySopJ mice with ubiquitous green fluorescent protein (GFP) expression ${ }^{7}$ or $\mathrm{CD}^{2} 5.1^{+}$B6.SJL-Ptprc ${ }^{\mathrm{a}}$ $\mathrm{Pepc}^{\mathrm{b}} /$ BoyJ mice (The Jackson Laboratory, Bar Harbor,
ME). ${ }^{28}$ Recipients in C57BL/6J background were DPPIVmice $^{29}$ or IL6 knockout B6.129S2-Il6 ${ }^{\mathrm{tm} 1 \mathrm{Kopf}} / \mathrm{J}$ mice (The Jackson Laboratory). ${ }^{30}$ Mice were anesthetized with isoflurane. For cell transplantation, 1 to $2 \times 10^{6}$ of $\mathrm{KC}$,

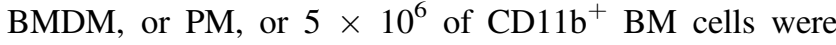
injected into portal vein or tail vein in $0.3 \mathrm{~mL}$ serum-free Dulbecco's Modified Eagle Medium.

To deplete KC, $10 \mathrm{mg} / \mathrm{kg} \mathrm{GdCl}$ (Sigma Chemical Co.), or 100 to $200 \mu \mathrm{L}$ liposomal clodronate (ClodronateLiposomes.org, Amsterdam, the Netherlands), ${ }^{31,32}$ were given via tail vein in saline. Controls received empty liposomes or saline. Residual $\mathrm{KC}$ were analyzed by flow cytometry in NPC isolated by collagenase digestion. KC phagocytosis was analyzed by 1 hour pulse of carbon 24 hours after gadolinium chloride or clodronate as described. ${ }^{2}$ Cells were transplanted 24 hours after gadolinium chloride administration.

For hepatic IL-6 expression, $5.5 \mathrm{mg} / \mathrm{kg}$ lipopolysaccharide (Sigma Chemical Co.) was given i.p. in saline 6 hours before analysis.

\section{Liver Injury Models}

For hepatic IR, the porta hepatis of 8- to 10-week-old C57BL/6 male mice was clamped for 15 minutes followed by reperfusion. After 5 minutes, 2.5 to $3 \times 10^{6} \mathrm{GFP}+\mathrm{KC}, 5 \times 10^{6}$ $\mathrm{GFP}^{+} \mathrm{CD} 11 \mathrm{~b}^{+} \mathrm{BM}$ cells, or vehicle phosphate-buffered saline (PBS) were injected intraportally $(n=3$ to 4$)$. For APAP injury, 8- to 10-week-old C57BL/6J male mice were fasted overnight and given $\mathrm{LD}_{50}$ dose of $500 \mathrm{mg} / \mathrm{kg}$ APAP i.p. After 6 to 8 hours, 2.5 to $3 \times 10^{6} \mathrm{GFP}+\mathrm{KC}, 5 \times 10^{6} \mathrm{GFP}^{+} \mathrm{CD} 11 \mathrm{~b}^{+}$ BM cells, TTFs, or vehicle were given intraportally $(n=3$ to 4$)$. Mice were sacrificed after 1 day and 7 days for histology and cell engraftment evaluations.

\section{Cell Isolation and Culture}

Mouse liver was perfused as described previously. ${ }^{2}$ Cell viability was determined by trypan blue dye exclusion. Hepatocytes were removed by pelleting under $50 \times g$ for 5 minutes. Red blood cells were lyzed. Remaining NPC were incubated with biotin-conjugated anti-CD11b and biotinconjugated anti-F4/80 (eBioscience, San Diego, CA) for 20 minutes at $4^{\circ} \mathrm{C}$ followed by incubation with Streptavidin MicroBeads (Miltenyi Biotec, San Diego, CA) for 15 minutes at $4^{\circ} \mathrm{C}$, and cells then were isolated by MS Separation Columns (Miltenyi Biotec), according to manufacturer guidelines. Cell separation was verified by fluorescence-activated cell sorting (BD Biosciences, San Jose, CA). KC were cultured in Iscove's Modified Dulbecco's Medium (Sigma-Aldrich) containing $10 \%$ fetal bovine serum (FBS) and $5 \mathrm{ng} / \mathrm{mL}$ recombinant mouse macrophage-colony stimulating factor (R\&D Systems, Minneapolis, MN). PM were isolated by two washes of peritoneal cavity from GFP + mice with Dulbecco's modified Eagle's medium (Sigma-Aldrich) containing 10\% FBS. Cells were isolated with biotin-conjugated anti-CD11b and anti-F4/80 as described previously in this paragraph. BM 
Table 1 Antibodies Used for Fluorescence-Activated Cell Sorting

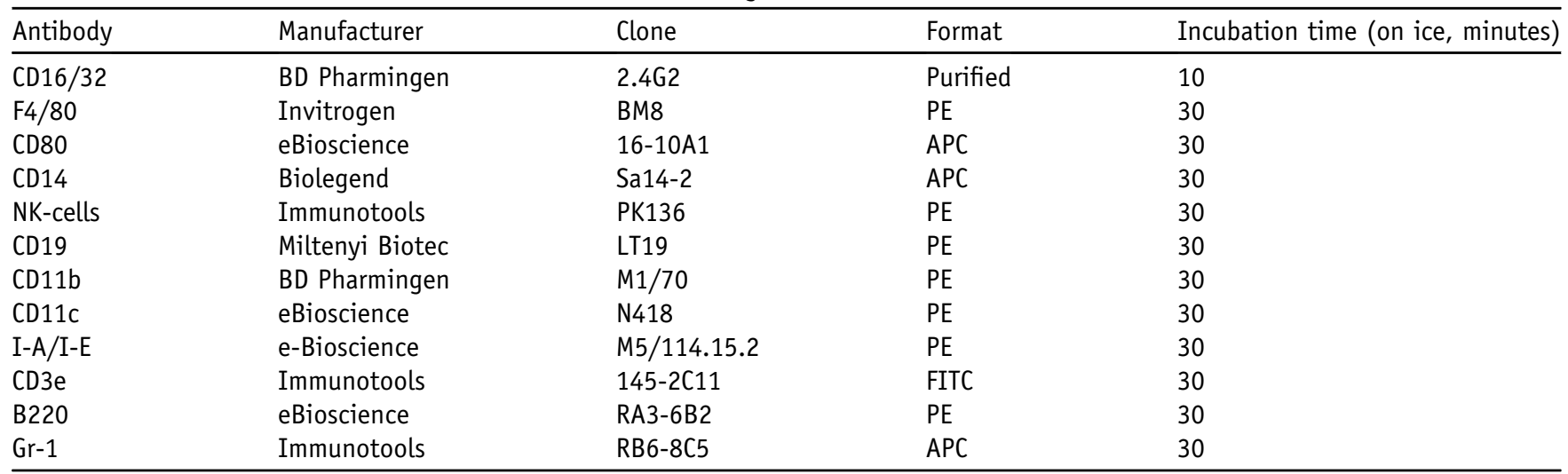

APC, allophycocyanin; FITC, fluorescein isothiocyanate; PE, phycoerythrin.

cells were flushed out of tibias and femurs from mice with Dulbecco's modified Eagle's medium with 5\% FBS. Red blood cells were lyzed and CD11 $\mathrm{b}^{+}$BM cells were isolated as described previously in this paragraph. Moreover, 0.8 to $1 \times 10^{6}$ of total BM cells $/ \mathrm{cm}^{2}$ plastic were differentiated in Iscove's Modified Dulbecco's Medium containing $10 \%$ FBS and $5 \mathrm{ng} / \mathrm{mL}$ recombinant mouse macrophage colonystimulating factor for 5 to 7 days, after which cells were released by Versene (Gibco). TTFs were isolated from 3- to 4-week-old $\mathrm{GFP}^{+}$mice. Tails were sterilized in $70 \%$ ethanol, skinned, and minced thoroughly. Minced pieces were placed under glass coverslip in 6-well plates (one tailtip in each well) for culture in Dulbecco's modified Eagle's medium with $10 \%$ FBS. After 5 to 7 days in culture, coverslips and minced pieces were removed, and TTFs were expanded with fresh medium every other day until confluent. For transplantation, 1 to $2 \times 10^{6}$ freshly isolated

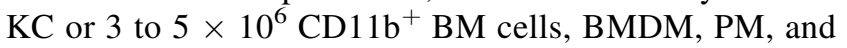
TTFs were administered per mouse.

\section{Fluorescence-Activated Cell Sorting}

Cells were incubated with antibodies (Table 1), washed, and resuspended in $2 \% \mathrm{FBS}$ in $\mathrm{PBS}, \mathrm{pH}$ 7.4. For each sample, $1 \times 10^{5}$ events were acquired by FACScalibur (BD
Biosciences). Data were analyzed by Windows Multiple Document Interface for Flow Cytometry (winMDI, v. 2.9; Joseph Trotter, The Scripps Institute, La Jolla, CA).

\section{Biodistribution Studies}

Cells ( 1.5 to $2 \times 10^{6}$ ) were incubated in $2 \mathrm{~mL}$ saline with 370 to $555 \mathrm{MBq}{ }^{99 \mathrm{~m}} \mathrm{Tc}$ (Ultratag and Ceretec kits; Mallinckrodt, St. Louis, MO) or $15 \mathrm{MBq}{ }^{111}$ In-oxine for 30 minutes at room temperature, as described previously. ${ }^{1}$ Labeling efficiencies were measured. Cell viability was evaluated by trypan blue dye. Total body static images were obtained 30 minutes after cell transplantation. Liver, spleen, lungs, kidneys, and muscle were collected after 1 hour for radioactivity.

\section{Tissue Studies}

Liver samples were fixed in formalin for hemoatoxylin and eosin staining or in $4 \%$ paraformaldehyde in PBS, equilibrated in $15 \%$ and $30 \%$ sucrose, embedded in optimum cooling temperature compound (Tissue-Tek, Sakura Finetek, Torrance, CA), and frozen at $-80^{\circ} \mathrm{C}$. Cryosections $(5 \mu \mathrm{m})$ were post-fixed with paraformaldehyde for 5 minutes at room temperature, blocked with $5 \%$ goat serum, $1 \%$ bovine serum albumin, and $0.1 \%$ Triton X-100 (Sigma-Aldrich) in PBS,

Table 2 Antibodies Used for Immunofluorescence

\begin{tabular}{|c|c|c|c|c|}
\hline Antibodies & Manufacturer & Clone & Dilution & $\begin{array}{l}\text { Incubation time } \\
\text { at room temperature }\end{array}$ \\
\hline \multicolumn{5}{|l|}{ Primary antibodies } \\
\hline $\mathrm{F} 4 / 80$ & AbD Serotec (Bio-Rad, Raleigh, NC) & CI:A3-1 & $1: 500$ & 1 hour \\
\hline $\mathrm{CD} 68$ & AbD serotec & FA-11 & $1: 500$ & 1 hour \\
\hline GFP & Molecular Probes & Rabbit polyclonal & $1: 300$ & 1 hour \\
\hline CD45.1 & eBioscience & $\mathrm{A} 20$ & $1: 50$ & 1 hour \\
\hline \multicolumn{5}{|l|}{ Secondary antibodies } \\
\hline Goat anti-rat IgG & Molecular Probes & Alexa Fluor 546 or 488 -conjugated & $1: 500$ & $45-60$ minutes \\
\hline Goat anti-rabbit IgG & Molecular Probes & Alexa Fluor 488-conjugated & $1: 500$ & $45-60$ minutes \\
\hline
\end{tabular}


Table 3 RT-PCR Primers and Expected Products

\begin{tabular}{|c|c|c|c|c|c|c|}
\hline Primer name & Forward primer & Reverse primer & $\begin{array}{l}\mathrm{Tm} \\
\left({ }^{\circ} \mathrm{C}\right)\end{array}$ & $\begin{array}{l}\text { PCR } \\
\text { cycles }\end{array}$ & $\begin{array}{l}\text { Amplicon } \\
\text { (bp) }\end{array}$ & $\begin{array}{l}\text { Polymerase } \\
\text { used }\end{array}$ \\
\hline $\begin{array}{l}\text { Human } \\
\text { VEGFires-GFP }\end{array}$ & $\begin{array}{l}\text { 5'-GGCAGCTTGAGTTAAA- } \\
\text { CGAAC- } 3^{\prime}\end{array}$ & 5'-CACACCGGCCTTATTCC-3' & 55 & 35 & 152 & $\begin{array}{l}\text { GoTaq Flexi DNA } \\
\text { Polymerase (Promega, } \\
\text { Madison, WI) }\end{array}$ \\
\hline Mouse IL-1 $\beta$ & $\begin{array}{l}5^{\prime}-\text { GCTGTCCTGATGAGAG- } \\
\text { CATCC }-3^{\prime}\end{array}$ & $\begin{array}{l}5^{\prime}-\text { CATGAGTCACAGAGGATG- } \\
\text { GGCTC-3' }\end{array}$ & 60 & 30 & 199 & $\begin{array}{l}\text { GoTaq Flexi DNA } \\
\text { Polymerase }\end{array}$ \\
\hline Mouse IL-10 & $\begin{array}{l}5^{\prime}-\text { CCTGGCTCAGCACTGC- } \\
\text { TATGC }-3^{\prime}\end{array}$ & $\begin{array}{l}\text { 5'-TTAGCTTTTCATTTTGAT- } \\
\text { CATCATG-3' }\end{array}$ & 60 & 30 & 534 & $\begin{array}{l}\text { GoTaq Flexi DNA } \\
\text { Polymerase }\end{array}$ \\
\hline Mouse IL-12 $\alpha$ & $\begin{array}{l}5^{\prime}-\text { GAATTCCAGGCCATCA- } \\
\text { ACGCA-3' }\end{array}$ & $\begin{array}{l}5^{\prime} \text { - GAAGGCGTGAAGCAGGAT- } \\
\text { GCAG- } 3^{\prime}\end{array}$ & 60 & 30 & 198 & $\begin{array}{l}\text { GoTaq Flexi DNA } \\
\text { Polymerase }\end{array}$ \\
\hline Mouse IL-12 $\beta$ & $\begin{array}{l}5^{\prime}-\text { CGTGCTCATGGCTGGT- } \\
\text { GCAAAGA-3' }\end{array}$ & $\begin{array}{l}\text { 5'-CAGGGTCTCCTCGGCAGT- } \\
\text { TG-3' }\end{array}$ & 60 & 30 & 200 & $\begin{array}{l}\text { GoTaq Flexi DNA } \\
\text { Polymerase }\end{array}$ \\
\hline
\end{tabular}

GFP, green fluorescent protein; VEGF, vascular endothelial growth factor.

and incubated with rabbit anti-GFP or anti-vascular endothelial growth factor (VEGF) or rat anti-mouse F4/80. For CD45.1 staining, sections were post-fixed for 10 minutes in ice-cold acetone, blocked, and probed with anti-mouse CD45.1 labeled with Zenon Alexa Fluor 488 Mouse IgG $_{2 a}$ kit (Molecular Probes, Thermo Fisher Scientific, Waltham, MA). Sections were incubated with Alexa Fluor 488-conjugated goat anti-rabbit IgG and/or Alexa Fluor 546-conjugated goat anti-rat IgG (Molecular Probes), with DAPI-Antifade (Molecular Probes) for nuclear counterstaining. For cell proliferation, sections were permeabilized for 10 minutes in ice-cold $1 \%$ Triton X-100 in PBS, blocked as above, and stained with rabbit anti-Ki67 and rat anti-mouse F4/80 antibodies. Localization used Alexa Fluor 488-conjugated goat anti-rat IgG and Alexa Fluor 546-conjugated goat anti-rabbit antibodies. Primary and secondary antibodies are listed in Table 2. Sections were counterstained with DAPI or TO-PRO-3 and examined by Observer.Z1 fluorescence microscope (Carl Zeiss Microimaging Inc., Thornwood, NY) or Leica confocal microscopy TSP2 (Leica Microsystems, Buffalo Grove, IL).

\section{Transduction}

LVs were prepared as described previously. ${ }^{33}$ Cells were transduced with 5 to 20 multiplicities of infection ${ }^{34}$ of following vectors: pCCLsin.PPT.hPGK.eGFP.pre LV (LV-PGK-GFP) (control); vector substituting hPGK

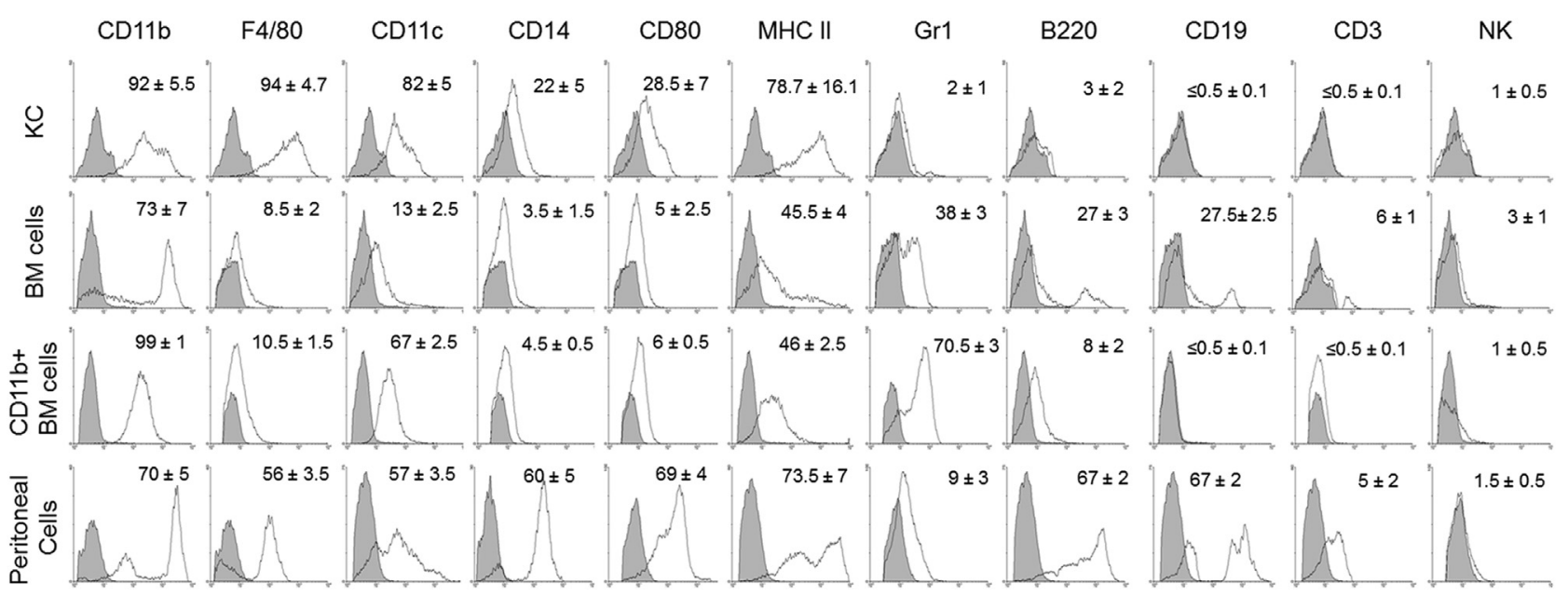

Figure 1 Cell characterization. Fluorescence-activated cell sorting for various cell surface markers indicated in freshly isolated Kupffer cells, bone marrow cells, CD11 $b^{+}$BM cells and peritoneal cells. Numbers represent means \pm SD of at least five experiments. BM, bone marrow; Gr1, lymphocyte antigen 6 complex, locus G; KC, Kupffer cells; MHC II, major histocompatibility complex class II; NK, natural killer. 
A

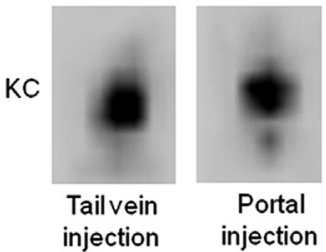

C
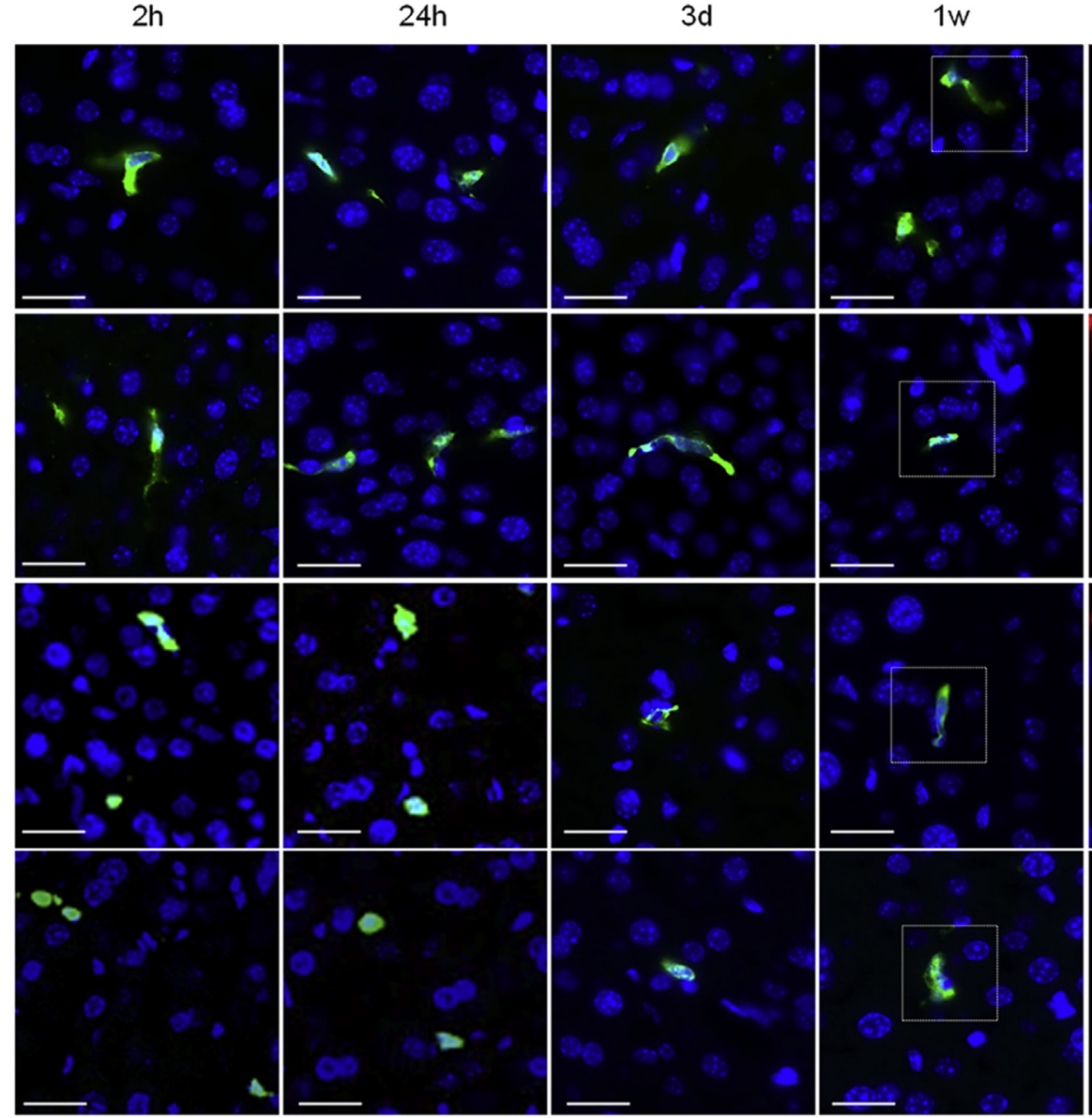

D

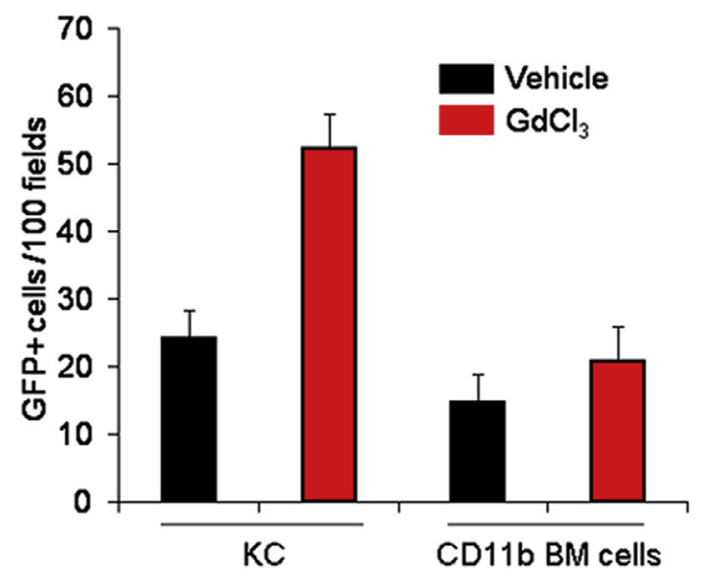

B

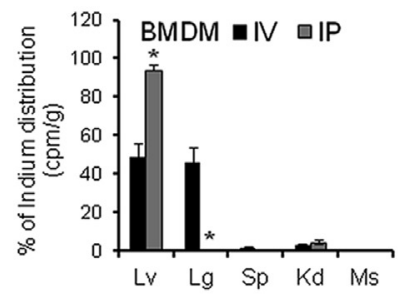
GFP + F4/80

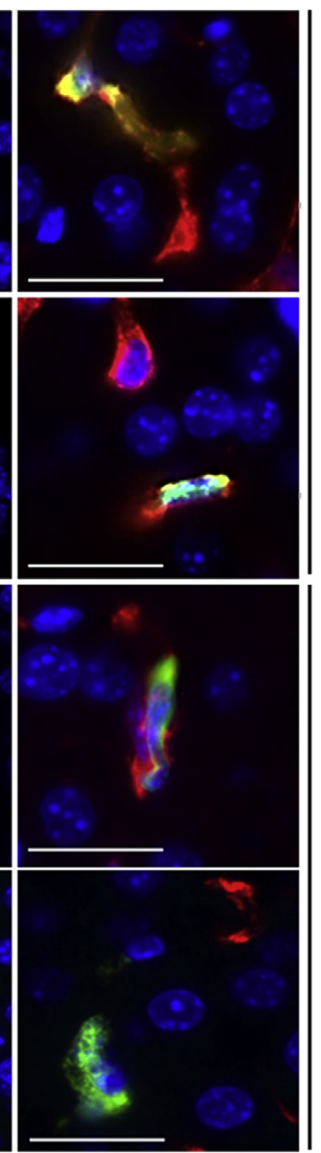

$+\mathrm{GdCl}_{3}$

$-\mathrm{GdCl}_{3}$

$+\mathrm{GdCl}_{3}$

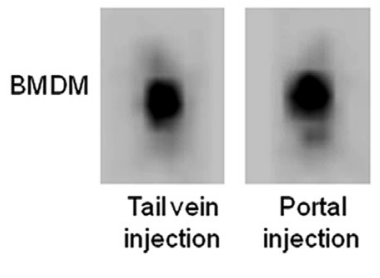

Boxed areas $1 \mathrm{~W}$

CD11b ${ }^{+}$ BM cells

Figure 2 Targeting of radiolabeled cells and engraftment of transplanted green fluorescent protein (GFP) ${ }^{+}$cells in liver. $\mathbf{A}$ and $\mathbf{B}$ : Representative images 30 minutes after i.p. $(n=5)$ and i.v. $(n=4)$ injection of ${ }^{111}$ In-labeled Kupffer cells (KC) (A) or bone marrow-derived monocyte/macrophage (BMDM) (B). Charts indicate distribution of organ activity after 1 hour. I.P. versus I.V. injection was more effective for delivering cells to liver: $\mathrm{KC}, 88 \% \pm 3 \%$ versus $48 \% \pm 17 \%$; BMDM, $94 \% \pm 3 \%$ versus $49 \% \pm 7 \%$. More cells were entrapped in lungs after IV versus IP injection: KC, $42 \% \pm 19 \%$ versus $6 \% \pm 2 \%$; BMDM, $46 \% \pm 8 \%$ versus $1 \% \pm 0.4 \%$. Similarly, more cells entered spleen after IV injection: $\mathrm{KC}, 7 \% \pm 2 \%$ versus $1 \pm 0.3 ; \mathrm{BMDM}, 2 \% \pm 0.3 \%$ versus $0.4 \% \pm 0.1 \%$. Cells were similarly distributed in kidneys or muscle. C: DPPIV - recipients 1 week after transplantation of $\mathrm{KC}$ or $\mathrm{CD}_{11} \mathrm{~b}^{+}$bone marrow cells with and without gadolinium chloride. Panels on extreme right provide magnified views. Identity of $\mathrm{GFP}^{+}$transplanted cells (green) was verified by F4/80 costaining (red). More cells engrafted after gadolinium chloride. However, CD11b ${ }^{+}$BM cells engrafted less well versus KC. D: Morphometric analysis of $K C$ and $C D 11 b^{+} B M$ cell engraftment after 1 week. ${ }^{*} P<0.05$. Scale bars: $20 \mu \mathrm{m}(\mathbf{C})$. $\mathrm{GdCl}_{3}$, gadolinium chloride; Kd, kidneys; Ms, muscle; Lg, lungs; Lv, liver; Sp, spleen. 

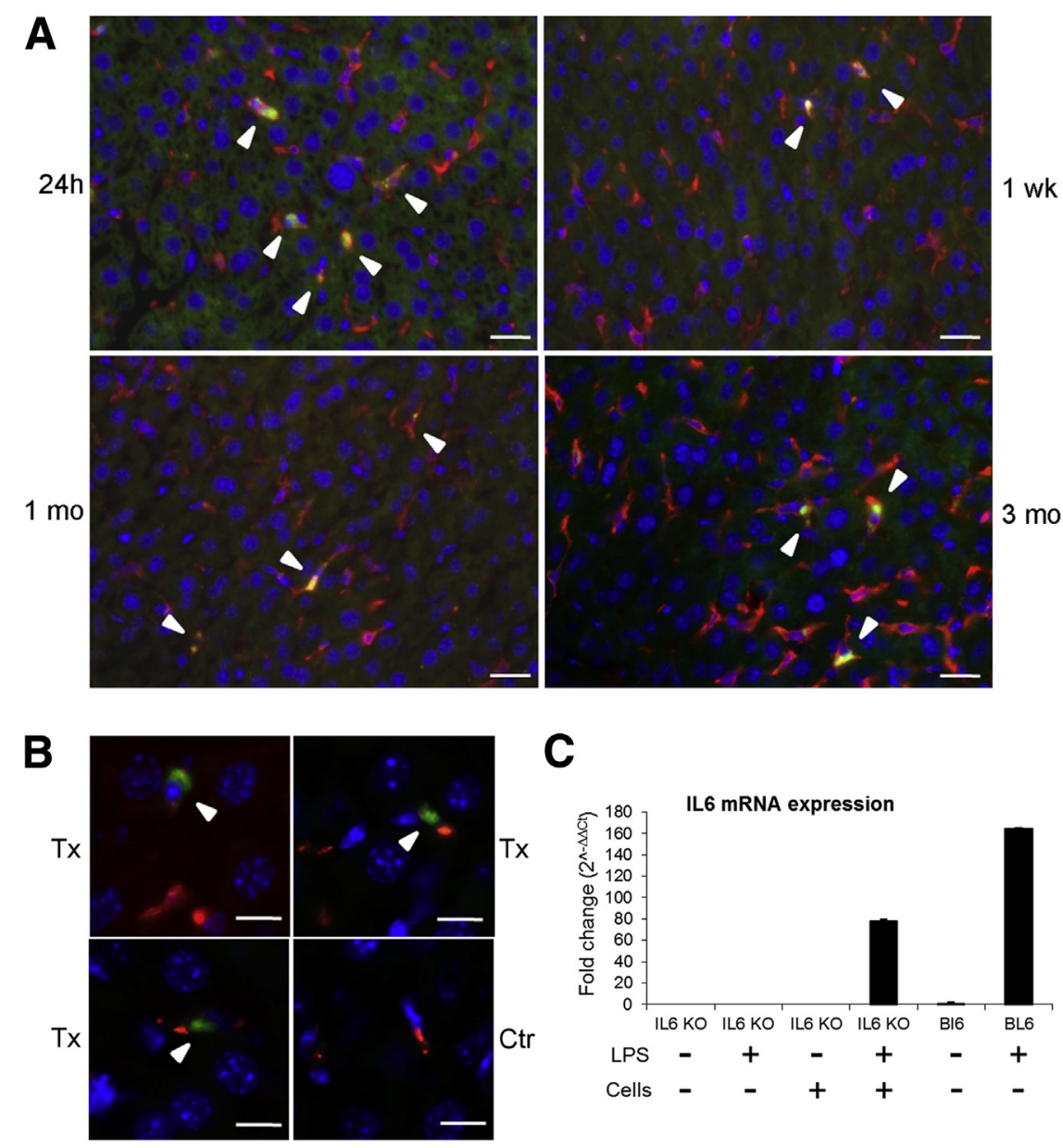

Figure 3 Long-term survival and functionality of transplanted Kupffer cells (KC). A: Identification in liver of transplanted $\mathrm{KC}$ with immunostaining for CD45.1 (green) and F4/80 (red) (arrowheads) after 24 hours, 1 week, 1 month, and 3 months. B: Phagocytosis of Ds-Red ${ }^{+}$Escherichia coli in transplanted CD45.1 $1^{+} \mathrm{KC}$ (green) (arrowheads) 2 weeks after transplantation. C: Quantitative RT-PCR for IL-6 mRNA in IL- 6 knockout and wild-type C57BL/6 mice 5 days after KC transplantation. IL- 6 was expressed after $\mathrm{KC}$ transplantation. Scale bars: 20 $\mu \mathrm{m}$ (A and B). BL6, wild-type C57BL/6 mice; Ctr, control mouse liver; K0, knockout; LPS, lipopolysaccharide; Tx, transplantation.

promoter with myeloid-preferred $\mathrm{CD} 11 \mathrm{~b}$ promoter $(\mathrm{LV}$ CD11b-GFP), ${ }^{35}$ or vector with VEGF cDNA in bicistronic cassette (LV-PGK-VEGFiresGFP). To genetically modify $\mathrm{KC}$ in vivo, C57BL/6J mice were given $5 \times 10^{8}$ transduction units ${ }^{23}$ of LV to express GFP under monocyte/ macrophage specific promoter, CD11b (LV-CD11b-GFP), or $8 \times 10^{8} \mathrm{TU}$ of bicistronic LV expressing VEGF, and GFP with internal ribosomal entry site (IRES) under ubiquitous phosphoglycerate kinase (PGK) promoter (LV-PGK-VEGFiresGFP). VEGF cDNA was a gift from late Dr. Bruce Terman (Albert Einstein College of Medicine, New York, NY).

\section{RT-PCR and Quantitative RT-PCR}

Total RNA was isolated by Trizol reagent (Invitrogen, Thermo Fisher Scientific) and treated with DNase I (RNase-free DNase; Qiagen, Germantown, MD). cDNAs were generated from $1 \mu \mathrm{g}$ total RNA with Omniscript RT Kit (Qiagen). PCR products were resolved in 2\% agarose gels. For quantitative RT-PCR, cDNAs were generated from $2 \mu \mathrm{g}$ total RNA by $\mathrm{RT}^{2}$ First Strand Kit, followed by $\mathrm{RT}^{2}$ SYBR Green qPCR Master Mix (SABiosciences, Qiagen), $\mathrm{RT}^{2}$ qPCR Primer Assay for mouse IL-6 and GAPDH (SABiosciences) with ABIprism7000 software version 1.2.3 (Applied Biosystems, Inc., Thermo Scientific). Primers with expected product sizes are listed in Table 3.

\section{Blood Tests}

Blood was collected from animals in various groups. Serum was separated and stored at $-80^{\circ} \mathrm{C}$. This was followed by measurement of ALT levels with a commercial kit (ALTGPT LR; Gesan, Campobello di Mazara, Italy). Differences in animal groups were then compared.

\section{Statistics}

Data are shown as means \pm SD. Significances were analyzed by Student's $t$-test, $\chi^{2}$, or analysis of variance with Tukey or Bonferroni post-hoc tests by SigmaStat version 3.1 (Systat Software Chicago, IL). $P<0.05$ was considered significant.

\section{Results}

\section{Characterization of $\mathrm{KC}, \mathrm{PM}$, and $\mathrm{BMDM}$}

Typically, we isolated 1.5 to $2.5 \times 10^{6} \mathrm{KC}$ per mouse with $\geq 90 \%$ viability. KC expressed monocyte/macrophage 


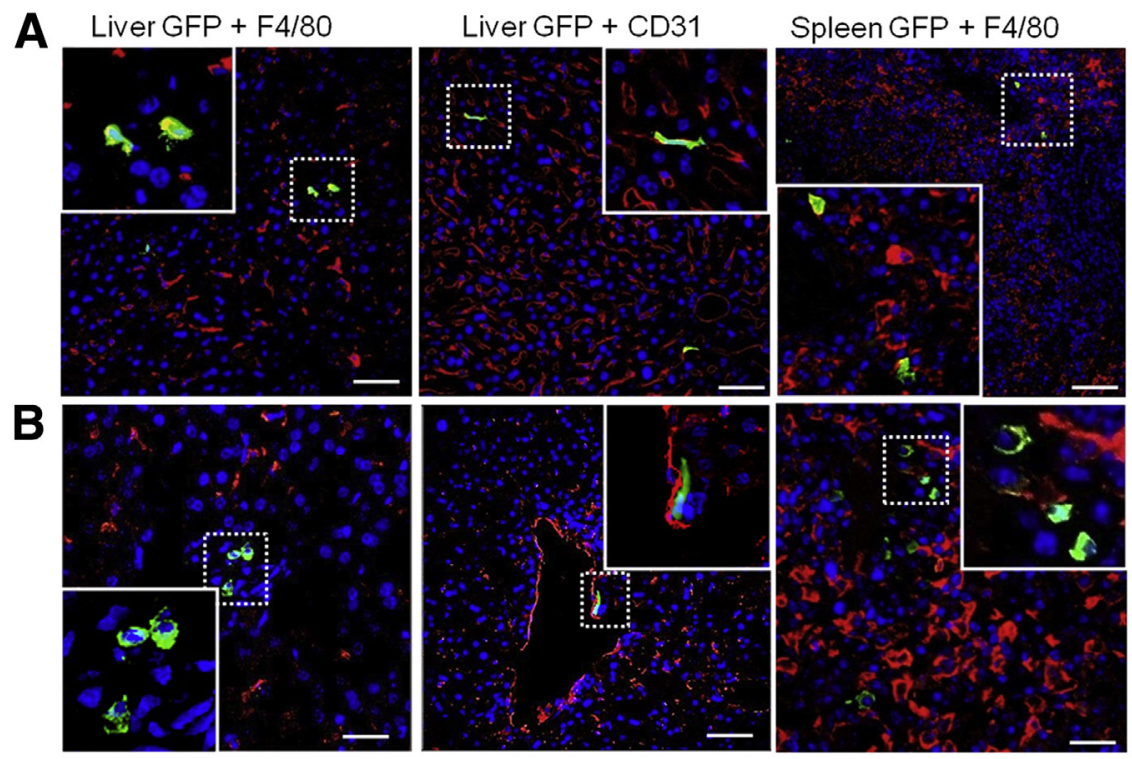

C
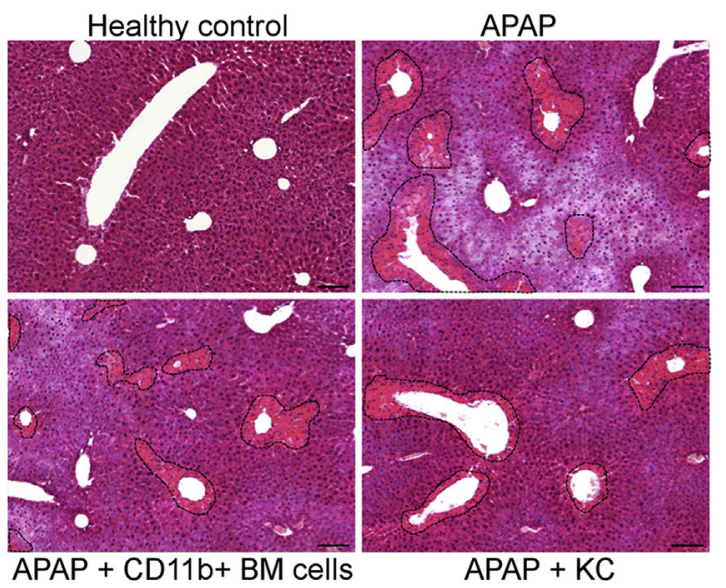

D

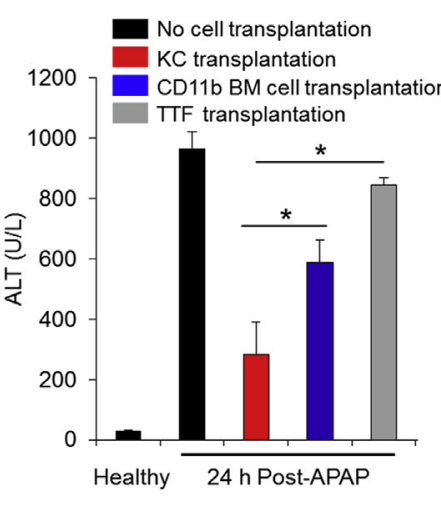

E

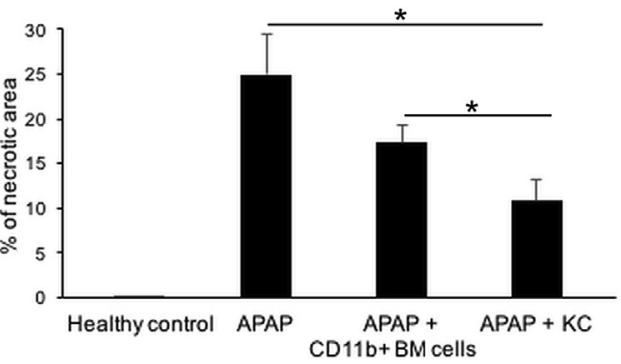

Figure 4 Hepatoprotective effects of transplanted Kupffer cells (KC) and $\mathrm{CD}_{11} \mathrm{~b}^{+}$bone marrow (BM) cells. A and B: Transplanted KC or $\mathrm{CD}_{11 b^{+}} \mathrm{BM}$ cells in liver and spleen of acetaminophen (APAP)-treated mice after 1 week. Green fluorescent protein (GFP) ${ }^{+}$transplanted cells (green) express macrophage marker, F4/80 (red), but not endothelial marker, CD31 (red) (middle panels). Magnified views (approximately threefold of areas indicated) of areas outlined in dotted lines are provided in insets in solid lines. C: Hematoxylin and eosin staining of livers from healthy control mouse, mouse given APAP alone with extensive necrosis, mouse with APAP plus transplantation of $\mathrm{CD} 11 \mathrm{~b}^{+} \mathrm{BM}$ cells with significant necrosis, and mouse with APAP plus transplantation of $\mathrm{KC}$ with less necrosis. D: Serum alanine aminotransferase levels after 24 hours with or without transplantation of $\mathrm{KC}$ or $\mathrm{CD}_{11 \mathrm{~b}^{+} \mathrm{BM}}$ cells in APAP-treated mice. Transplanted KC (2.5 to $3 \times 10^{6}$ ) were more effective than $\mathrm{CD}_{11 b^{+}} \mathrm{BM}$ cells $\left(5 \times 10^{6}\right)$, whereas transplantation of tail-tip fibroblasts $\left(5 \times 10^{6}\right)$ did not significantly decrease alanine aminotransferase levels. E: Morphometric quantification of necrotic areas in mice $(n=3$ each) versus healthy controls 24 hours after transplantation. APAP-induced necrosis decreased more after transplantation of $K C$ than $\mathrm{CD}_{11} \mathrm{~b}^{+} \mathrm{BM}$ cells. ${ }^{*} P<0.05$. Scale bars: $50 \mu \mathrm{m}(\mathbf{A}$ and $\mathbf{B}) ; 100$ $\mu \mathrm{m}(\mathrm{C})$. ALT, alanine aminotransferase; TTF, tailtip fibroblasts. markers, CD11b, and F4/80, at medium-high levels, and CD11c, at a medium level. Low-level expression of CD14 and CD80 in isolated $\mathrm{KC}$ indicated that these were distinct from dendritic cells. Isolated $\mathrm{KC}$ expressed major histocompatibility complex II marker, but not other leukocyte markers [ie, Gr-1 (granulocytes), B220 or CD19 (B cells), or CD3 (T cells)] (Figure 1). By contrast, freshly-isolated $\mathrm{BM}$ cells and $\mathrm{CD} 11 \mathrm{~b}^{+} \mathrm{BM}$ cells showed high levels of CD11b and low levels of F4/80 expression, indicating that these were primarily monocyte/macrophage precursor cell populations (Figure 1). BMDM expressed CD11b at medium-high level and F4/80 and CD11c at low levels. PM expressed CD11b and F4/80 at high levels and CD11c at medium level (Supplemental Figure S1A). After culture, F4/80 expression was readily detected by immunostaining in 


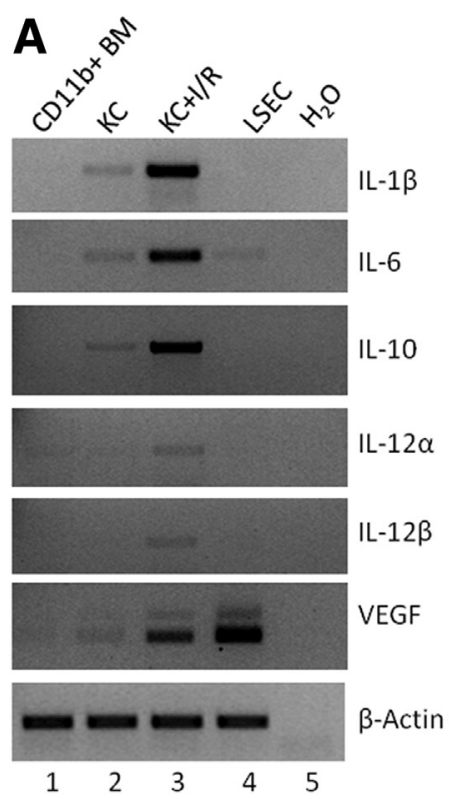

B
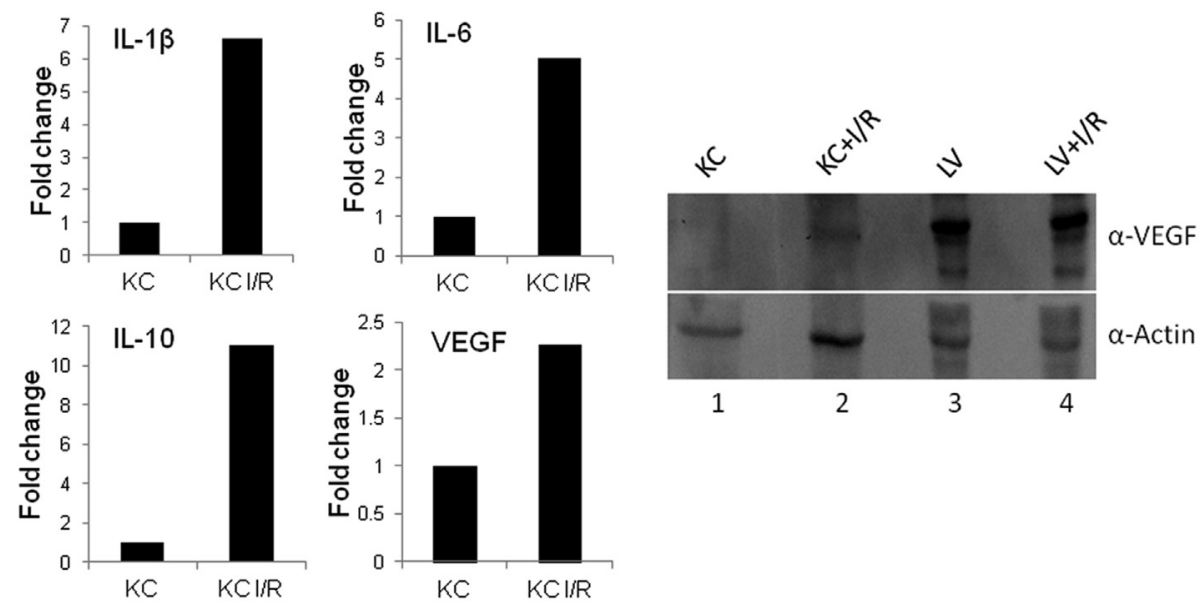

Figure 5 Cytokine expression in freshly isolated cells. A: RT-PCR for cytokine mRNAs as indicated in CD11b ${ }^{+}$BM cells (lane 1), Kupffer cells (KC) from healthy control liver (lane 2), KC from liver 2 hours after ischemia-reperfusion (IR) injury (lane 3), healthy liver sinusoidal endothelial cells (LSEC) (lane 4), and negative control (lane 5). B: Densitometry for IL-1B, IL-6, IL-10, and vascular endothelial growth factor mRNAs showing 6.6-, 5-, 11- and 2.3-fold increases after IR, respectively. C: Greater vascular endothelial growth factor expression in KC after IR is confirmed by Western blot analysis. LSEC, liver sinusoidal endothelial cells; VGEF, vascular endothelial growth factor.

KC, BMDM, and PM (Supplemental Figure S1B), which verified macrophage phenotypes.

\section{Hepatic Targeting and Engraftment of Transplanted Cells}

For optimal cell transplantation route, we radiolabeled $\mathrm{KC}$ and BMDM and found these incorporated ${ }^{111}$ In equally $(65 \pm 4 \%$ efficiency) but neither cell type incorporated ${ }^{99 \mathrm{~m}}$ Tc. More cells entered the liver after i.p. $(n=5)$ versus i.v. $(n=4)$ injection in 30 to 60 minutes (Figure 2, A and B). Therefore, we injected cells in all studies with i.p. route.

After transplantation in DPPIV- mice, $\mathrm{GFP}_{+} \mathrm{KC}$ engrafted in liver at 2 hours, 24 hours, 3 days, and 7 days (Figure 2C). To improve cell engraftment, we determined the effects of gadolinium chloride and clodronate on native KC 24 hours after administering these substances. Gadolinium chloride decreased $\mathrm{KC}$ to $27 \% \pm 2 \%$ of controls $(P<0.05)$, and carbon uptake to $60 \%$ of controls $(P<0.05)$. In low $(100 \mu \mathrm{L})$ or high dose $(200 \mu \mathrm{L})$, clodronate decreased $\mathrm{KC}$ numbers to $20 \% \pm 5 \%$ and $21 \% \pm 1 \%$, respectively, and carbon uptake to $60 \%$ to $70 \%$ of controls $(P<0.05)$ (Supplemental Figure S2). Therefore, both gadolinium chloride and clodronate decreased $\mathrm{KC}$ phagocytosis; clodronate depleted $\mathrm{KC}$ subpopulations without affecting $\mathrm{CD}_{11 \mathrm{~b}^{+}} \mathrm{KC}$ previously. ${ }^{9}$ In gadolinium chloride-treated mice, $\mathrm{GFP}^{+} \mathrm{F} 4 / 80^{+} \mathrm{KC}$ engrafted better (Figure $2 \mathrm{C}$ ). However, $\mathrm{GFP}^{+}$BMDM engrafted poorly, as these were found in liver after 2 hours but rarely after 24 hours, and not after 3 days or 7 days. Gadolinium chloride did not improve BMDM engraftment (Figure 2C). Similarly, PCR for DPPIV DNA-verified transplanted BMDM were present after 2 hours and not after 24 hours (Supplemental Figure S3A). Next, to determine whether freshly-isolated $\mathrm{CD}_{11 \mathrm{~b}^{+}} \mathrm{BM}$ cells might engraft better than BMDM, ${ }^{16}$ we isolated $\mathrm{CD}_{11} \mathrm{~b}^{+} \mathrm{BM}$ cells from $\mathrm{GFP}^{+}$donors followed by transplantation in mice. Transplanted $\mathrm{GFP}^{+} \mathrm{BM}$ cells were in liver up to 7 days after transplantation (Figure 2C), although in fewer numbers than transplanted $\mathrm{KC}$ at 7 days, $15 \pm 5$ versus $25 \pm 4$ cells per 100 fields $(P<0.05)$ (Figure $2 \mathrm{D}$ ). The number of transplanted $\mathrm{KC}$ in gadolinium chloride-treated mice was twofold greater after 7 days: $24 \pm 3$ cells (controls) versus $50 \pm 2$ cells (gadolinium chloride-treated) per 100 fields $(P<0.05)$. More $\mathrm{GFP}^{+} \mathrm{CD} 11 \mathrm{~b}^{+} \mathrm{BM}$ cells engrafted in the liver of gadolinium chloride-treated mice after 7 days, but this was less than $\mathrm{KC}(21 \pm 4$ versus $53 \pm 5$ cells per 100 fields [1.4- versus 2.2-fold increase from controls]) $(P<0.05)$ (Figure 2D). However, BM cells were distributed additionally to the spleen as described in Hepatoprotective Potential of Transplanted $\mathrm{KC}$ and $\mathrm{CD}_{11 b^{+}} \mathrm{BM}$ Cells. Donor BM cells were rarely $\mathrm{F} 4 / 80^{+}$, indicating that they did not produce mature macrophages. When $\mathrm{GFP}^{+} \mathrm{PM}$ were transplanted, these engrafted inefficiently in liver, 0 to 5 PM per 100 fields after 3 days, and none were found after 7 days, indicating that $\mathrm{KC}$ had predilection for liver (Supplemental Figure S3).

Long-Term Survival of Transplanted KC with Retention of Macrophage Functions

For these studies, we used CD45.1 C57B1/6 donors to avoid immunogenicity of GFP. In DPPIV - recipients, transplanted $\mathrm{CD} 45.1 / \mathrm{F} 4 / 80 / \mathrm{CD} 11 \mathrm{~b}^{+} \mathrm{KC}$ were present in liver after 24 


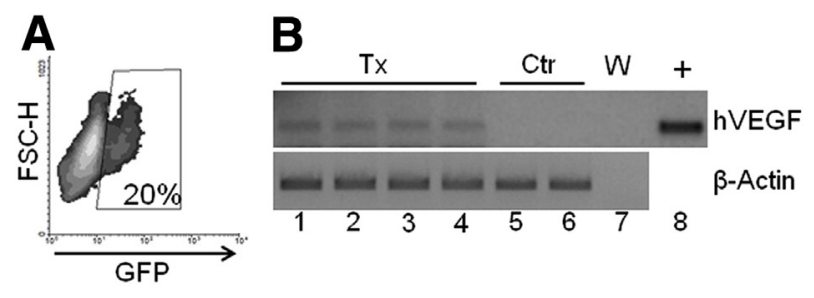

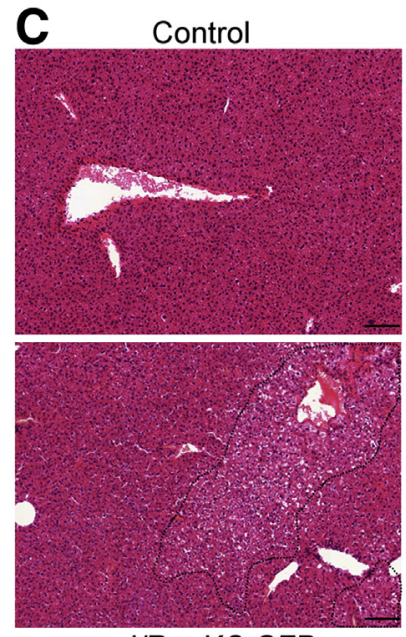

$\mathrm{I} / \mathrm{R}+\mathrm{KC}$ GFP

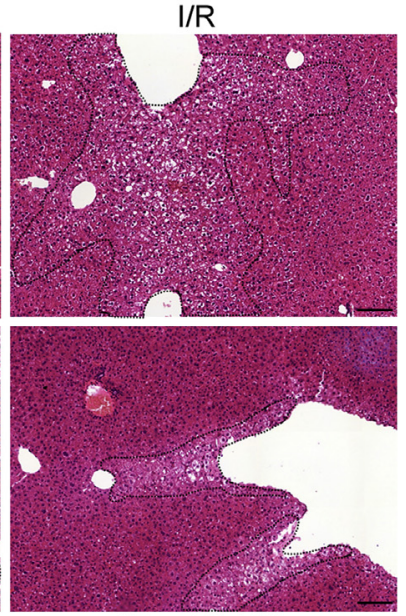

$\mathrm{I} / \mathrm{R}+\mathrm{KC} \mathrm{VIG}$

\section{D}

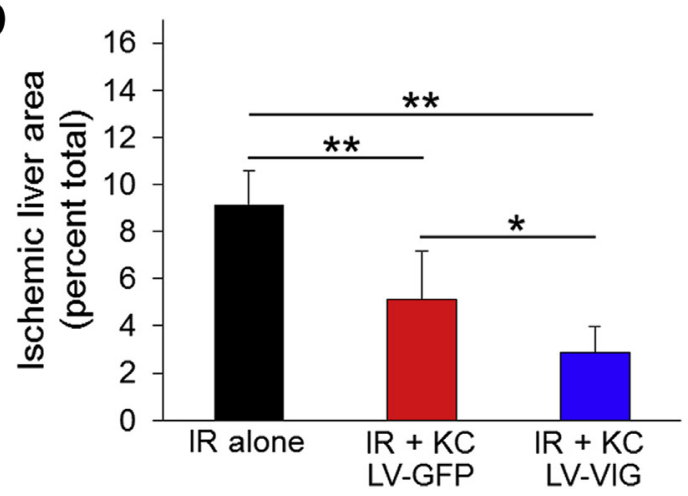

Figure 6 Lentiviral vectors (LV)-transduced Kupffer cells (KC) decrease ischemia-reperfusion injury. A: Fluorescence-activated cell sorting showing green fluorescent protein (GFP) in $20 \%$ of freshly isolated KC from mouse given LV.PGK-hVEGF-ires-GFP (VIG) 1 week previously. B: RT-PCR for hepatic hVEGF mRNA 1 week after cell transplantation. Lanes 1 to 4 , recipients of KC + VIG; lanes 5 and 6 , control mice; lane 7, water alone; lane 8 , positive control PGK-hVEGF-ires-GFP cDNA. C: Hematoxylin and eosin staining showing necrotic areas. Necrotic areas are outlined by black lines in other panels. In comparison with healthy controls, ischemia-reperfusion causes significant necrosis. Liver necrosis is lessened in recipients of transplanted LV-GFP-transduced KC (KC-GFP) and decreases further in recipients of KC expressing additional vascular endothelial growth factor (KC-VIG). D: Liver necrosis is less 1 day after cell transplantation especially when LVVIG transduced KC are transplanted, indicating benefits of additional vascular endothelial growth factor. ${ }^{*} P<0.05,{ }^{* *} P<0.01$. Scale bars: $100 \mu \mathrm{m}$ (C). $\mathrm{I} / \mathrm{R}$, ischemia-reperfusion; VEGF, vascular endothelial growth factor.

hours, 1 week, 1 month, and 3 months ( $n=3$ to 4 each) (Figure 3A). Therefore, transplanted KC survived essentially indefinitely. In gadolinium chloride-treated DPPIV - mice, phagocytosis of DH5 $\alpha$ Escherichia coli expressing DsRed was identified in transplanted $\mathrm{CD} 45.1^{+} \mathrm{KC}$ by immunostaining after 2 weeks (Figure 3B). In gadolinium chloride-treated
IL-6 knockout mice, transplantation of healthy $\mathrm{GFP}^{+} \mathrm{KC}$ led to the appearance of lipopolysaccharide-inducible IL- 6 mRNA expression when examined after 5 days, as another property of macrophages (Figure 3C).

\section{Hepatoprotective Potential of Transplanted KC and CD11b ${ }^{+}$BM Cells}

To examine additional biological effects of transplanted KC, we studied mice with APAP hepatotoxicity. We noted differences in distributions of transplanted $\mathrm{KC}$ and $\mathrm{CD} 11 \mathrm{~b}^{+}$ $\mathrm{BM}$ cells in APAP-treated mice 1 week after transplantation. More transplanted KC were in the liver (12 per 20 fields) than spleen ( 3 per 20 fields), but more transplanted $\mathrm{CD} 11 \mathrm{~b}^{+} \mathrm{BM}$ cells were in the spleen $(35$ per 20 fields) than liver (6 per 20 fields) $(P<0.05)$ (Figure 4, A and B, and Supplemental Figure S4). Given that twice as many $\mathrm{BM}$ cells were transplanted than $\mathrm{KC}$, the overall number of transplanted cells in these two organs was not significantly different. After 1 week, transplanted $\mathrm{GFP}^{+} \mathrm{CD} 11 \mathrm{~b}^{+} \mathrm{BM}$ cells were rarely $\mathrm{F} 4 / 80^{+}$, indicating that liver injury had not induced these to differentiate into mature macrophages. Liver injury decreased when either $\mathrm{KC}$ or $\mathrm{CD} 11 \mathrm{~b}^{+} \mathrm{BM}$ cells were transplanted (Figure $4 \mathrm{C}$ ). The alanine aminotransferase levels were lower, particularly after transplantation of KC (Figure 4D). Morphometric analysis confirmed decreases in liver necrosis in these animals 24 hours after cell transplantation, including recipients of transplanted KC (Figure 4E). By comparison, transplantation of TTFs had no significant effect on either serum alanine aminotransferase levels (Figure 4D) or liver histology (not shown) in APAPtreated mice. To determine whether these beneficial effects of transplanted KC may have involved angiogenic modulators $\left(\mathrm{eg}, \mathrm{VEGF}^{36}\right.$ ) or anti-inflammatory cytokines (eg, IL-10 ${ }^{12,37}$ ), we examined this further by transplanting genetically modified $\mathrm{KC}$.

After transduction with LVs, the GFP transgene was expressed efficiently under the PGK promoter (LV-PGKGFP) in cultured mouse KC and BMDM. Similarly, cultured $\mathrm{KC}$ and BMDM expressed GFP under the monocyte/macrophage promoter, CD11b (LV-CD11bGFP) (Supplemental Figure S5). As freshly isolated KC proved difficult to transduce by $\mathrm{LV}$ in vitro (5\% to $10 \%$ ), we gave $5 \times 10^{8}$ transducing units of LV-CD11b-GFP to donor C57BL/6J mice by tail vein injection followed by isolation of $\mathrm{KC}$ after 1 week. The cell yield was similar to healthy donor mice, and we isolated approximately $2 \times 10^{6} \mathrm{KC}$ from these LV-transduced donor mice. We found $55 \% \pm 9 \%$ of isolated $\mathrm{KC}$ were positive for both $\mathrm{F} 4$ / 80 and GFP (Supplemental Figure S6). These LVtransduced $\mathrm{GFP}^{+} \mathrm{KC}$ were localized in liver 1 week after transplantation in gadolinium chloride-preconditioned C57BL6/J mice.

In animals subjected to IR, analysis of $\mathrm{KC}$ isolated after 2 hours showed expression of inflammatory cytokines [IL-1 $\beta$ 
(6.6-fold), IL-6 (fivefold), IL-12 $\alpha$, and IL-12 (twofold)] along with anti-inflammatory cytokines [IL-10 (11-fold), VEGF (2.3-fold)] (Figure 5, A-C).

To establish whether additional VEGF expression in KC would further increase hepatoprotection, we subjected C57BL/6 mice to IR and then immediately transplanted KC isolated from healthy donor $\mathrm{C} 57 \mathrm{BL} / 6 \mathrm{~J}$ mice $(n=3$ to 4 each) that had been transduced with either LV-PGK-VEGFires-GFP (LV-VIG) or LV-PGK-GFP (LV-GFP) 1 week previously. In mice with IR followed immediately by transplantation of LV-transduced KC expressing VEGF, liver necrosis decreased further 1 day after transplantation, indicating that VEGF was beneficial, as assessed by histology and quantification of ischemic areas (Figure 6, C and D). These LV-transduced $\mathrm{KC}$ were found to have engrafted in the liver along with presence of VEGF and GFP expression 1 week after IR and cell transplantation (Supplemental Figure S7, A and B).

\section{Discussion}

These studies established that transplanted $\mathrm{KC}$ engrafted and survived over the long term in the liver. Retention of appropriate macrophage functions in transplanted $\mathrm{KC}$, particularly in a context-specific manner, indicated that replacement of these cells will provide important means to address the biological and therapeutic potential of monocyte/macrophage cell types.

Our studies did not address the trafficking and exchange of cells from BM, peripheral blood, and tissues, which have been studied in extensive detail by other investigators, including in recent publications. ${ }^{38,39}$ Our focus concerned the fate and functionality of transplanted cells because of the relevance of this approach for biological or therapeutic studies. Although multiple macrophage and monocyte populations may express F4/80 and CD11b, besides cell types such as neutrophils, we eliminated circulating or loosely adherent monocytes or other cells from isolated cells by clearing blood from donor livers before enzymatic digestion to release firmly adherent $\mathrm{KC}$. Moreover, positive selection of $\mathrm{KC}$ with immunobeads requiring significant amounts of $\mathrm{CD} 11 \mathrm{~b}$ and $\mathrm{F} 4 / 80$ expression would have avoided contamination by cells with only lowlevel expression of these markers. In healthy donor livers, we found no evidence of macrophage tissue invasion to consider such contaminants. Therefore, $\mathrm{KC}$ isolates lacking markers found in other white blood cell populations, robust macrophage functions such as phagocytosis, bacterial clearance, inflammatory cytokine expression in response to lipopolysaccharide, expression of cytokines observed in macrophages, plus the fact that transplantation of these $\mathrm{KC}$ led to their engraftment in liver, whereas other macrophage populations or fibroblasts did not engraft, further corroborated that the cell isolation procedures yielded suitable KC.

We isolated BM cells and generated BMDM with established protocols. ${ }^{40}$ The vast majority of BMDM and
BM-derived cells were CD11b positive, and when these cells were Gr-1 positive, that was simultaneously with $\mathrm{CD} 11 \mathrm{~b}$ positivity, which is not typical of mature neutrophils. ${ }^{41}$ Generation of BMDM indicated that isolated BM cells contained substantial numbers of mononuclear cells or monocyte precursor cells. Similarly, PM and TTFs were isolated with established methods. ${ }^{42,43}$ Typical morphology and phenotype characterizations confirmed that these cells, too, were suitable for studies.

Remarkably, KC and BMDM incorporated ${ }^{111}$ In but not ${ }^{99 \mathrm{~m}} \mathrm{Tc}$, a property shared with liver sinusoidal endothelial cells, ${ }^{1}$ but not with hepatocytes, which incorporated both ${ }^{111}$ In and ${ }^{99 m} \mathrm{Tc} .{ }^{44}$ Besides the obvious differences in the morphology of hepatocytes and KC or BMDM, this finding confirmed that hepatocytes had not contaminated $\mathrm{KC}$ and $\mathrm{BMDM}$ preparations. As targeting of radiolabeled $\mathrm{KC}$ and BMDM to organs after intraportal or tail vein injection was similar, we could directly compare their fates. Because KC and BMDM largely were entrapped in lungs after tail vein injection, this finding also should be helpful for designing or interpreting cell transplantation studies.

Approximately $20 \%$ of transplanted KC engrafted in the liver in mice preconditioned with gadolinium chloride. This efficiency of transplanted cell engraftment recapitulated that, in cases of hepatocytes or liver sinusoidal endothelial cells, prior liver preconditioning involving endothelial or hepatic injury created room for transplanted cells and promoted their integration in niches. ${ }^{2,29,31}$ As $\mathrm{CD} 1 \mathrm{~b}^{+}$BM cells, BMDM, PM, and TTFs either engrafted poorly or did not engraft in liver, consideration of intrinsic properties determining cell adhesion or other engraftment mechanisms should be appropriate. For instance, adhesion of transplanted hepatocytes to liver sinusoidal endothelial cells via integrin-dependent interactions is an early step in their engraftment. ${ }^{45}$ Similarly, macrophage adhesion to endothelium requires $\mathrm{CD} 11 \mathrm{~b}$, which forms a subunit of heteromeric $\alpha \mathrm{M} \beta 2$ integrin. ${ }^{46}$ Elucidating whether this or similar molecules may contribute to KC engraftment could help in liver repopulation with these cells. Cytokines, such as hepatocyte growth factor, stromal cell-derived factor 1, or insulin-like growth factor 1, promote accumulation of hematopoietic cells in liver, ${ }^{47,48}$ but whether these contributed in engraftment of $\mathrm{KC}$ is unknown. Microcirculatory changes $^{49}$ (eg, release of vasoactive molecules and inflammatory cytokines/chemokines/receptors), interfere with hepatocyte engraftment ${ }^{50}$ and may have contributed in clearing of transplanted KC, BMDM, PM, or TTFs. Control of vascular and inflammatory perturbations has been useful for improving hepatocyte engraftment ${ }^{51,52}$ and may be helpful for KC engraftment, too.

After engraftment, transplanted $\mathrm{KC}$ survived for at least 3 months in the liver. Such longevity of KC had been unknown previously. This should be relevant for studying the biological roles of $\mathrm{KC}$ in immunological memory, antigen presentation, or homeostasis during liver injury. ${ }^{10-12}$ In their ontogeny, $\mathrm{KC}$ originate from 
mesodermal precursor cells in yolk sac and later appear in fetal liver. ${ }^{53,54}$ In adult liver, KC likely replenish from mononuclear cells arising in BM. Whether liver-resident $\mathrm{KC}$ could self-renew over the long term may be studied now by the cell transplantation approach. ${ }^{7,54}$ The difficulties in analyzing the fate and functions of $\mathrm{KC}$ within their native microenvironment led to generation of immortalized macrophage lines. ${ }^{55}$ Such immortalized macrophages, including those derived from pluripotent stem cells, gained broad interest. ${ }^{34}$ But studies of macrophage differentiation, fate, and function should benefit greatly from cell transplantation under specific liver microenvironment contexts in vivo.

We noted the ability of transplanted $\mathrm{KC}$ to express pro- and anti-inflammatory cytokines in a contextspecific manner (ie, after lipopolysaccharide or liver injury ${ }^{25}$ ), implying that transplanted KC flexibly adopted either pro- or anti-inflammatory phenotypes as was needed. Previously, when NPC, including KC, were cotransplanted with hepatocytes in the peritoneal cavity, transplanted hepatocytes showed superior survival. ${ }^{56}$ Therefore, cotransplantation of these cell types might be worth considering in applications of hepatocyte transplantation. Also, our results of improved outcomes in liver injury after transplantation of $\mathrm{KC}$, along with promotion of tissue repair through release of relevant cytokines (eg, $\operatorname{VEGF}^{57}$ ) were in agreement with this hepatoprotective ability of $\mathrm{KC}$. We do not imply that VEGF alone accounted for beneficial effects in this setting, because multiple cytokines are involved in hepatic injury. The hepatoprotective role of $\mathrm{KC}$ was in agreement with previous studies in which APAP toxicity in mice was worsened by prior depletion through clodronate of native $\mathrm{KC}$ with significantly decreased expression of multiple regulatory cytokines and molecules, including several interleukins. ${ }^{58}$ By contrast, freshly isolated CD11 $\mathrm{b}^{+} \mathrm{BM}$ cells and BMDM survived only briefly after transplantation without producing mature $\mathrm{KC}$ despite depletion of native $\mathrm{KC}$ by gadolinium chloride, and so this approach alone should not be effective for replacing KC. Previously, infusion of BMDM in a mouse model of fibrosis was beneficial even though transplanted cells were cleared within 1 week. ${ }^{16}$ In our studies, transplanted $\mathrm{KC}$ survived longer in the liver and directly supported liver repair or regeneration.

Another aspect of $\mathrm{KC}$ transplantation concerns genetic modification of cells before transplantation. Previously, nonintegrating adenoviral vectors were used to express hepatoprotective superoxide dismutase or heme oxygenase-1 genes in NPC, including KC, ${ }^{14}$ or BMDM. ${ }^{18}$ The ability to permanently transduce $\mathrm{KC}$ with LVs and then to successfully return these to the liver will have therapeutic relevance. For instance, healthy native monocytes and $\mathrm{KC}$ expressed coagulation factor VIII at low but sufficient levels for ameliorating coagulation defect in hemophilia A. ${ }^{15,59}$ This indicates that cell and gene therapy approaches should merit additional studies in hemophilia and other relevant conditions amenable to $\mathrm{KC}$ transplantation.

\section{Acknowledgments}

We thank Gertrude Ukpong, Alessio Stevano, and Sara Cristinelli for providing technical assistance. VEGF cDNA was a gift from the late Dr. Bruce Terman (Albert Einstein College of Medicine, New York, NY).

S.M. and A.F. designed and performed experiments, interpreted data, and wrote the article; G.R. and D.Z. performed experiments; K.K.B. and C.J.P. conducted radiolabeling and animal imaging studies; L.S. and M.P. provided conceptual advice; A.F. and S.G. designed the study, generated funding, and wrote the article.

\section{Supplemental Data}

Supplemental material for this article can be found at http://dx.doi.org/10.1016/j.ajpath.2015.11.002.

\section{References}

1. Benten D, Follenzi A, Bhargava KK, Kumaran V, Palestro CJ, Gupta S: Hepatic targeting of transplanted liver sinusoidal endothelial cells in intact mice. Hepatology 2005, 42:140-148

2. Follenzi A, Benten D, Novikoff P, Faulkner L, Raut S, Gupta S: Transplanted endothelial cells repopulate the liver endothelium and correct the phenotype of hemophilia A mice. J Clin Invest 2008, 118:935-945

3. Gupta S, Rajvanshi P, Aragona E, Lee CD, Yerneni PR, Burk RD: Transplanted hepatocytes proliferate differently after $\mathrm{CCl} 4$ treatment and hepatocyte growth factor infusion. Am J Physiol 1999, 276: G629-G638

4. Selmi C, Mackay IR, Gershwin ME: The immunological milieu of the liver. Semin Liver Dis 2007, 27:129-139

5. Crofton RW, Diesselhoff-den Dulk MM, van Furth R: The origin, kinetics, and characteristics of the Kupffer cells in the normal steady state. J Exp Med 1978, 148:1-17

6. Hume DA: The mononuclear phagocyte system. Curr Opin Immunol 2006, 18:49-53

7. Klein I, Cornejo JC, Polakos NK, John B, Wuensch SA, Topham DJ, Pierce RH, Crispe IN: Kupffer cell heterogeneity: functional properties of bone marrow derived and sessile hepatic macrophages. Blood 2007, 110:4077-4085

8. Kinoshita M, Uchida T, Sato A, Nakashima M, Nakashima H, Shono S, Habu Y, Miyazaki H, Hiroi S, Seki S: Characterization of two F4/80-positive Kupffer cell subsets by their function and phenotype in mice. J Hepatol 2010, 53:903-910

9. Ikarashi M, Nakashima H, Kinoshita M, Sato A, Nakashima M, Miyazaki H, Nishiyama K, Yamamoto J, Seki S: Distinct development and functions of resident and recruited liver Kupffer cells/macrophages. J Leukoc Biol 2013, 94:1325-1336

10. Breous E, Somanathan S, Vandenberghe LH, Wilson JM: Hepatic regulatory T cells and Kupffer cells are crucial mediators of systemic $\mathrm{T}$ cell tolerance to antigens targeting murine liver. Hepatology 2009 , 50:612-621

11. Chen Y, Liu Z, Liang S, Luan X, Long F, Chen J, Peng Y, Yan L, Gong J: Role of Kupffer cells in the induction of tolerance of orthotopic liver transplantation in rats. Liver Transpl 2008, 14: $823-836$ 
12. Ellett JD, Atkinson C, Evans ZP, Amani Z, Balish E, Schmidt MG, van Rooijen N, Schnellmann RG, Chavin KD: Murine Kupffer cells are protective in total hepatic ischemia/reperfusion injury with bowel congestion through IL-10. J Immunol 2010, 184: 5849-5858

13. Holt MP, Cheng L, Ju C: Identification and characterization of infiltrating macrophages in acetaminophen-induced liver injury. J Leukoc Biol 2008, 84:1410-1421

14. Froh M, Wheeler MD, Smutney O, Zhong Z, Bradford BU, Thurman RG: New method of delivering gene-altered Kupffer cells to rat liver: studies in an ischemia-reperfusion model. Gastroenterology 2003, 124:172-183

15. Follenzi A, Raut S, Merlin S, Sarkar R, Gupta S: Role of bone marrow cell transplantation for correcting hemophilia A in mice. Blood 2012, 119:5532-5542

16. Thomas JA, Pope C, Wojtacha D, Robson AJ, Gordon-Walker TT, Hartland S, Ramachandran P, Van Deemter M, Hume DA, Iredale JP, Forbes SJ: Macrophage therapy for murine liver fibrosis recruits host effector cells improving fibrosis, regeneration, and function. Hepatology 2011, 53:2003-2015

17. Wang J, Zhou X, Cui L, Yan L, Liang J, Cheng X, Qiao L, Shi Y, Han Z, Cao Y, Han Y, Fan D: The significance of CD14+ monocytes in peripheral blood stem cells for the treatment of rat liver cirrhosis. Cytotherapy 2010, 12:1022-1034

18. Shen XD, Ke B, Uchida Y, Ji H, Gao F, Zhai Y, Busuttil RW, Kupiec-Weglinski JW: Native macrophages genetically modified to express heme oxygenase 1 protect rat liver transplants from ischemia/reperfusion injury. Liver Transpl 2011, 17:201-210

19. Forbes SJ, Russo FP, Rey V, Burra P, Rugge M, Wright NA, Alison MR: A significant proportion of myofibroblasts are of bone marrow origin in human liver fibrosis. Gastroenterology 2004, 126: 955-963

20. Wilson HM, Stewart KN, Brown PA, Anegon I, Chettibi S, Rees AJ, Kluth DC: Bone-marrow-derived macrophages genetically modified to produce IL-10 reduce injury in experimental glomerulonephritis. Mol Ther 2002, 6:710-717

21. Yang CY, Chen JB, Tsai TF, Tsai YC, Tsai CY, Liang PH, Hsu TL, Wu CY, Netea MG, Wong CH, Hsieh SL: CLEC4F is an inducible Ctype lectin in F4/80-positive cells and is involved in alphagalactosylceramide presentation in liver. PLoS One 2013, 8:e65070

22. Duffield JS, Forbes SJ, Constandinou CM, Clay S, Partolina M, Vuthoori S, Wu S, Lang R, Iredale JP: Selective depletion of macrophages reveals distinct, opposing roles during liver injury and repair. J Clin Invest 2005, 115:56-65

23. Gautier EL, Shay T, Miller J, Greter M, Jakubzick C, Ivanov S, Helft J, Chow A, Elpek KG, Gordonov S, Mazloom AR, Ma'ayan A, Chua WJ, Hansen TH, Turley SJ, Merad M, Randolph GJ; Immunological Genome C: Gene-expression profiles and transcriptional regulatory pathways that underlie the identity and diversity of mouse tissue macrophages. Nat Immunol 2012, 13:1118-1128

24. Haldar M, Murphy KM: Origin, development, and homeostasis of tissue-resident macrophages. Immunol Rev 2014, 262:25-35

25. Mantovani A, Biswas SK, Galdiero MR, Sica A, Locati M: Macrophage plasticity and polarization in tissue repair and remodelling. J Pathol 2013, 229:176-185

26. Mosser DM, Edwards JP: Exploring the full spectrum of macrophage activation. Nat Rev Immunol 2008, 8:958-969

27. Ramachandran P, Pellicoro A, Vernon MA, Boulter L, Aucott RL, Ali A, Hartland SN, Snowdon VK, Cappon A, Gordon-Walker TT, Williams MJ, Dunbar DR, Manning JR, van Rooijen N, Fallowfield JA, Forbes SJ, Iredale JP: Differential Ly-6C expression identifies the recruited macrophage phenotype, which orchestrates the regression of murine liver fibrosis. Proc Natl Acad Sci U S A 2012, 109:E3186-E3195

28. Okabe M, Ikawa M, Kominami K, Nakanishi T, Nishimune Y: 'Green mice' as a source of ubiquitous green cells. FEBS Lett 1997, 407:313-319
29. Wu YM, Joseph B, Berishvili E, Kumaran V, Gupta S: Hepatocyte transplantation and drug-induced perturbations in liver cell compartments. Hepatology 2008, 47:279-287

30. Kopf M, Baumann H, Freer G, Freudenberg M, Lamers M, Kishimoto T, Zinkernagel R, Bluethmann H, Kohler G: Impaired immune and acute-phase responses in interleukin-6-deficient mice. Nature 1994, 368:339-342

31. Joseph B, Malhi H, Bhargava KK, Palestro CJ, McCuskey RS, Gupta S: Kupffer cells participate in early clearance of syngeneic hepatocytes transplanted in the rat liver. Gastroenterology 2002, 123: $1677-1685$

32. Ramos P, Casu C, Gardenghi S, Breda L, Crielaard BJ, Guy E, Marongiu MF, Gupta R, Levine RL, Abdel-Wahab O, Ebert BL, Van Rooijen N, Ghaffari S, Grady RW, Giardina PJ, Rivella S: Macrophages support pathological erythropoiesis in polycythemia vera and beta-thalassemia. Nat Med 2013, 19:437-445

33. Follenzi A, Naldini L: Generation of HIV-1 derived lentiviral vectors. Methods Enzymol 2002, 346:454-465

34. Kambal A, Mitchell G, Cary W, Gruenloh W, Jung Y, Kalomoiris S, Nacey C, McGee J, Lindsey M, Fury B, Bauer G, Nolta JA, Anderson JS: Generation of HIV-1 resistant and functional macrophages from hematopoietic stem cell-derived induced pluripotent stem cells. Mol Ther 2011, 19:584-593

35. Simard AR, Soulet D, Gowing G, Julien JP, Rivest S: Bone marrowderived microglia play a critical role in restricting senile plaque formation in Alzheimer's disease. Neuron 2006, 49:489-502

36. Riazy M, Chen JH, Steinbrecher UP: VEGF secretion by macrophages is stimulated by lipid and protein components of OxLDL via PI3-kinase and PKCzeta activation and is independent of OxLDL uptake. Atherosclerosis 2009, 204:47-54

37. Bourdi M, Masubuchi Y, Reilly TP, Amouzadeh HR, Martin JL, George JW, Shah AG, Pohl LR: Protection against acetaminopheninduced liver injury and lethality by interleukin 10: role of inducible nitric oxide synthase. Hepatology 2002, 35:289-298

38. Gosselin D, Link VM, Romanoski CE, Fonseca GJ, Eichenfield DZ, Spann NJ, Stender JD, Chun HB, Garner H, Geissmann F, Glass CK: Environment drives selection and function of enhancers controlling tissue-specific macrophage identities. Cell 2014, 159: $1327-1340$

39. Lavin Y, Winter D, Blecher-Gonen R, David E, Keren-Shaul H, Merad M, Jung S, Amit I: Tissue-resident macrophage enhancer landscapes are shaped by the local microenvironment. Cell 2014, 159: $1312-1326$

40. Fleetwood AJ, Lawrence T, Hamilton JA, Cook AD: Granulocytemacrophage colony-stimulating factor (CSF) and macrophage CSFdependent macrophage phenotypes display differences in cytokine profiles and transcription factor activities: implications for CSF blockade in inflammation. J Immunol 2007, 178:5245-5252

41. Delano MJ, Scumpia PO, Weinstein JS, Coco D, Nagaraj S, Kelly-Scumpia KM, O’Malley KA, Wynn JL, Antonenko S, Al-Quran SZ, Swan R, Chung CS, Atkinson MA, Ramphal R, Gabrilovich DI, Reeves WH, Ayala A, Phillips J, Laface D, Heyworth PG, Clare-Salzler M, Moldawer LL: MyD88-dependent expansion of an immature GR-1 $(+) \mathrm{CD} 11 \mathrm{~b}(+)$ population induces $\mathrm{T}$ cell suppression and Th2 polarization in sepsis. J Exp Med 2007, 204:1463-1474

42. Ray A, Dittel BN: Isolation of mouse peritoneal cavity cells. J Vis Exp 2010, 35:1488

43. Seluanov A, Vaidya A, Gorbunova V: Establishing primary adult fibroblast cultures from rodents. J Vis Exp 2010, 44:2033

44. Cheng K, Benten D, Bhargava K, Inada M, Joseph B, Palestro C, Gupta S: Hepatic targeting and biodistribution of human fetal liver stem/progenitor cells and adult hepatocytes in mice. Hepatology 2009, 50:1194-1203

45. Kumaran V, Joseph B, Benten D, Gupta S: Integrin and extracellular matrix interactions regulate engraftment of transplanted hepatocytes in the rat liver. Gastroenterology 2005, 129:1643-1653 
46. Schmid MC, Avraamides CJ, Foubert P, Shaked Y, Kang SW, Kerbel RS, Varner JA: Combined blockade of integrin-alpha4betal plus cytokines SDF-1alpha or IL-1beta potently inhibits tumor inflammation and growth. Cancer Res 2011, 71:6965-6975

47. Kollet O, Shivtiel S, Chen YQ, Suriawinata J, Thung SN, Dabeva MD, Kahn J, Spiegel A, Dar A, Samira S, Goichberg P, Kalinkovich A, Arenzana-Seisdedos F, Nagler A, Hardan I, Revel M, Shafritz DA, Lapidot T: HGF, SDF-1, and MMP-9 are involved in stress-induced human $\mathrm{CD} 34+$ stem cell recruitment to the liver. J Clin Invest 2003, 112:160-169

48. Lehwald N, Duhme C, Wildner M, Kuhn S, Furst G, Forbes SJ, Jonas S, Robson SC, Knoefel WT, Schmelzle M, Schulte Am Esch J: HGF and SDF-1-mediated mobilization of CD133+ BMSC for hepatic regeneration following extensive liver resection. Liver Int 2014, 34:89-101

49. Slehria S, Rajvanshi P, Ito Y, Sokhi RP, Bhargava KK, Palestro CJ, McCuskey RS, Gupta S: Hepatic sinusoidal vasodilators improve transplanted cell engraftment and ameliorate microcirculatory perturbations in the liver. Hepatology 2002, 35:1320-1328

50. Krohn N, Kapoor S, Enami Y, Follenzi A, Bandi S, Joseph B, Gupta S: Hepatocyte transplantation-induced liver inflammation is driven by cytokines-chemokines associated with neutrophils and Kupffer cells. Gastroenterology 2009, 136:1806-1817

51. Bahde R, Kapoor S, Bandi S, Bhargava KK, Palestro CJ, Gupta S: Directly acting drugs prostacyclin or nitroglycerine and endothelin receptor blocker bosentan improve cell engraftment in rodent liver. Hepatology 2013, 57:320-330

52. Viswanathan P, Kapoor S, Kumaran V, Joseph B, Gupta S: Etanercept blocks inflammatory responses orchestrated by TNF-alpha to promote transplanted cell engraftment and proliferation in rat liver. Hepatology 2014, 60:1378-1388

53. Naito M, Hasegawa G, Takahashi K: Development, differentiation, and maturation of Kupffer cells. Microsc Res Tech 1997, 39: 350-364

54. Schulz C, Gomez Perdiguero E, Chorro L, Szabo-Rogers H, Cagnard N, Kierdorf K, Prinz M, Wu B, Jacobsen SE, Pollard JW, Frampton J, Liu KJ, Geissmann F: A lineage of myeloid cells independent of Myb and hematopoietic stem cells. Science 2012, 336: 86-90

55. Peng Y, Murr MM: Establishment of immortalized rat Kupffer cell lines. Cytokine 2007, 37:185-191

56. Selden C, Calnan D, Morgan N, Wilcox H, Carr E, Hodgson HJ: Histidinemia in mice: a metabolic defect treated using a novel approach to hepatocellular transplantation. Hepatology 1995, 21: $1405-1412$

57. Bussolati B, Ahmed A, Pemberton H, Landis RC, Di Carlo F, Haskard DO, Mason JC: Bifunctional role for VEGF-induced heme oxygenase-1 in vivo: induction of angiogenesis and inhibition of leukocytic infiltration. Blood 2004, 103:761-766

58. Ju C, Reilly TP, Bourdi M, Radonovich MF, Brady JN, George JW, Pohl LR: Protective role of Kupffer cells in acetaminophen-induced hepatic injury in mice. Chem Res Toxicol 2002, 15:1504-1513

59. Zanolini D, Merlin S, Feola M, Ranaldo G, Amoruso A, Gaidano G, Zaffaroni M, Ferrero A, Brunelleschi S, Valente G, Gupta S, Prat M, Follenzi A: Extrahepatic sources of factor VIII potentially contribute to the coagulation cascade correcting the bleeding phenotype of mice with hemophilia A. Haematologica 2015, 100:881-892 